\title{
Role of the Various Surface Sites and Species in CO Hydrogenation Over Alumina-supported Co-Pd Catalysts
}

\author{
(1) Maya G. Shopska,* Iskra Z. Shtereva, (1) Hristo G. Kolev, Krasimir K. Tenchev, Silviya Z. Todorova, Georgi B. Kadinov
}

Institute of Catalysis, Bulgarian Academy of Sciences, Acad. G. Bonchev St., Bldg. 11, 1113 Sofia, Bulgaria
* Corresponding author's e-mail addresses: shopska@ic.bas.bg, maya11may@abv.bg

RECEIVED: May 15, 2020 * REVISED: November 3, 2020 * ACCEPTED: November 4, 2020

Abstract: The paper is focused on evaluation of active centres and impact of adsorbed species on $(10 \% \mathrm{Co}+0.5 \% \mathrm{Pd}) / \mathrm{Al}_{2} \mathrm{O}_{3}$ catalyst system performance aiming selectivity optimization. Application of different sets of precursor pretreatment and reduction resulted in catalysts exhibiting high CO conversion or high methane selectivity. A sample of high selectivity was prepared by pretreatment in hydrogen and the performance was determined by lower amount of strongly adsorbed CO, strongly adsorbed carbonate species, and higher amount of reduced metal and bimetallic particles. A more active system was formed by pretreatment in air leading to larger amount of unreduced metal and CO-bridged species on the surface, stable coverage of hydroxyl groups on the support, and medium-strength sites for adsorption of carbonates. Ratios of hydrogen to carbon monoxide adsorption $(\mathrm{H} / \mathrm{CO}$ ) and of strongly to weakly adsorbed $\mathrm{CO}$ species appeared as important criteria for catalyst efficiency together with supported metal state, amount of unreduced ions, bimetallic particle formation, and alumina's ability to adsorb $\mathrm{CO}_{\text {and }} \mathrm{CO}_{2}$.

Keywords: Co-Pd catalysts, $\mathrm{CO}$ hydrogenation, $\mathrm{H}_{2}$ and $\mathrm{CO}$ chemisorption, in situ DRIFTS, surface sites, adsorbed species, activity, selectivity, TPR, TPD, XPS.

\section{INTRODUCTION}

$\mathrm{CO}$ HYDROGENATION is considered in present times an important process applied for diversification of fuel sources through Fischer-Tropsch synthesis, production of chemicals as oxygenates and/or various hydrocarbons, and biomass conversion including coal liquefaction. Catalysts meeting the green chemistry postulates should be possibly more selective, featuring a decreased variety of intermediates to avoid unnecessary by-product synthesis, and thus achieving higher conversion of the reagents into target products. ${ }^{[1]}$ The main reactions in the $\mathrm{CO}$ hydrogenation process are synthesis of $\mathrm{CH}_{4}$ and higher/other hydrocarbons and water-gas shift reaction (WGSR). Cobalt and cobalt-based catalysts are active in the formation of long chain hydrocarbons, and exhibit higher resistance to deactivation and low WGS activity compared to iron. ${ }^{[2,3]}$ Palladium has very good adsorption capacity for $\mathrm{CO}$ and $\mathrm{H}_{2}$, and manifests excellent hydrogenation properties and low activity in WGSR. In this connection, Co-Pd catalysts have demonstrated good activity in $\mathrm{CO}$ hydrogenation and attracted great attention. ${ }^{[2,4-8]} \mathrm{Co}$ and $\mathrm{Pd}$ differ in $\mathrm{CO}$ adsorption - associative on $\mathrm{Pd}{ }^{[9]}$ but associative as well dissociative on $\mathrm{Co}^{\left[{ }^{[-11]}\right.}$ dependent on temperature, surface coverage, and presence of other adsorbent.

The diversity of adsorption properties leads to different products of $\mathrm{CO}$ hydrogenation: methane and methanol can be obtained with palladium catalysts ${ }^{[12-14]}$ while hydrocarbons of various composition are produced in presence of cobalt catalysts. ${ }^{[4]}$

A mutual interaction between these metals in bimetallic catalyst systems causes also enhanced reduction of cobalt, decreased palladium particle agglomeration, and alloy formation. [7,15-17] All these promote changes in specific surface area like increased stability with temperature and occurrence of new adsorption sites with modified properties. At a mixed metal surface $\mathrm{Co}$ and $\mathrm{Pd}$ expose many typical and modified adsorption sites with different properties and varying concentration. ${ }^{[15]}$ Adsorption of hydrogen and $\mathrm{CO}$ and adsorption sites are interdependent significantly, as adsorption is an important 
stage in a heterogeneous catalytic reaction mechanism. Changes in adsorption properties of catalytically active components may lead to variation of catalyst activity, selectivity, and performance as well as enriched composition of the reaction products and variable quota of different hydrocarbons. The role of support is also very important by contributing to increase metal dispersion and thermal stability, and exposing various adsorption sites to reagents, intermediates, and reaction products. ${ }^{[18-23]}$ Many studies have been concerned with evaluation of the various factors determining activity and selectivity of cobalt-based catalysts in $\mathrm{CO}$ hydrogenation. These involve amount of deposited metal, type of support, promoters, catalyst preparation and activation mode, persistence of water and other components in the reaction mixture, diversity of adsorption sites on the supported metal and CO ability to form different species, and reaction conditions as pressure, $\mathrm{H}_{2} / \mathrm{CO}$ ratio in syngas, reactor type, flow rate, and temperature. Such a great number of factors that may affect catalyst performance render difficulties to create uniform theory about the $\mathrm{CO}$ hydrogenation reaction mechanism. ${ }^{[4,23-33]}$

Some previous studies ${ }^{[34]}$ invoked our interest on the effect of catalyst preparation on the ratio and interrelation among the various adsorbed species which could be related to catalyst activity and selectivity. This study is aimed at evaluating the role of catalyst precursor pretreatment and reduction mode in forming various metallic and metal oxide phases on the catalyst surface of the $(10 \% \mathrm{Co}+0.5 \% \mathrm{Pd}) /$ $\mathrm{Al}_{2} \mathrm{O}_{3}$ system and identifying the adsorbed species formed on the metal surface during $\mathrm{CO}$ hydrogenation. In the paper, some elements of simplification concerning operating pressure, $\mathrm{H}_{2} / \mathrm{CO}$ syngas ratio, and reaction temperature were accepted. It is known that methane is the only hydrocarbon synthesized at atmospheric pressure. ${ }^{[23]}$ The $\mathrm{H}_{2} / \mathrm{CO}$ ratio value is important to exploit fully the hydrogenating properties of $\mathrm{Co}$ as catalyst and it has been established that the minimal required value is 2.1. ${ }^{[4]} \mathrm{A}$ favourable $\mathrm{H}_{2} / \mathrm{CO}$ ratio for methanation is 3.3. The reaction temperature should be selected bearing in mind that the hydrogenation and carbon chain increase reactions are exothermal. ${ }^{[4,33]}$ Our previously reported experiments at 1 atm have shown that raising the reaction temperature increases the production of $\mathrm{CH}_{4}$ but also of undesired $\mathrm{CO}_{2} \cdot{ }^{[34]}$ Lower reaction temperatures hinder coke deposition on the surface and water-gas shift reaction as a source of $\mathrm{CO}_{2}$.

\section{EXPERIMENTAL}

Bimetallic catalysts were prepared by deposition of metal nitrate salts on Degussa-P110C1 non-porous $\mathrm{Al}_{2} \mathrm{O}_{3}\left(90 \mathrm{~m}^{2} / \mathrm{g}\right)$ through evaporation at $60{ }^{\circ} \mathrm{C}$ under vacuum of alumina suspension in salts solution. The procedure involved preset loading of 10 and $0.5 \%$ of cobalt and palladium, respectively.
Preliminary treatment of the precursors comprised consecutive heating for $1 \mathrm{~h}$ in a proper gas flow at 100, 200, and $300^{\circ} \mathrm{C}$ at a ramp rate of $100 \mathrm{deg} / \mathrm{h}$. Air, hydrogen, or argon were used for oxidative, reductive, or inert pretreatment. The $(10 \% \mathrm{Co}+0.5 \% \mathrm{Pd}) / \mathrm{Al}_{2} \mathrm{O}_{3}$ catalyst samples thus obtained were named (ox), (red), or (inert), respectively. A number of methods were used to characterize each sample.

Chemisorption of hydrogen and carbon monoxide was measured by the volumetric method in a glass device. The experiments were performed with samples reduced in the same device with hydrogen flow at different temperatures. Adsorption isotherms were obtained in the pressure range of $0-13.3 \mathrm{kPa}$. Hydrogen adsorption was conducted at $100{ }^{\circ} \mathrm{C}$ to minimize absorption in the bulk of palladium ${ }^{[35]}$ and to activate adsorption on cobalt ${ }^{[36,37]}$ whereas carbon monoxide chemisorption was done at room temperature. Strongly bonded $\mathrm{CO}\left(\mathrm{CO}_{\mathrm{s}}\right)$ was estimated as a difference between total and reversible (weak) adsorption. ${ }^{[38]}$

Ex-situ transmission electron microscopy (TEM) was used to obtain information about general structural characteristics of the catalysts. TEM pictures were collected by means of Topcon transmission electron microscope with $200 \mathrm{kV}$ accelerating voltage, resolution of $1 \mathrm{~nm}$ and object magnification of 100 to $2 \times 10^{6}$. Energy dispersive $X$-ray analysis (EDX) was applied for determination of the chemical composition in selected parts ( $14 \mathrm{~nm}$ in diameter) of the samples.

Catalytic activity measurements in the CO hydrogenation process were carried out in a flow type glass reactor at atmospheric pressure in the temperature range of $150-360{ }^{\circ} \mathrm{C}$. Catalyst loading was $140 \mathrm{mg}(0.63-0.8 \mathrm{~mm}$ fraction). $\mathrm{A} \mathrm{H}_{2} / \mathrm{CO}$ reaction mixture (4/1) was used at a flow rate of $25 \mathrm{ml} / \mathrm{min}$. The mixture at reactor outlet was analysed by a Varian 3700 gas chromatograph with thermal conductivity detector $\left(T=60^{\circ} \mathrm{C}, T_{\text {filament }}=80^{\circ} \mathrm{C}\right), 2 \mathrm{~m}$ Porapak Q column (0.150-0.180 mm, Riedel-de Haen AG D3016 Seelze 1), and hydrogen carrier gas at $20 \mathrm{ml} / \mathrm{min}$. Experimental setup for catalytic activity measurements is shown in Scheme 1.

The simple normalization method was used for quantitative analysis of reaction products and unreacted $\mathrm{CO}$. The carbon-containing compounds in the outlet gas stream were determined by the formula $X_{i}=\left(S_{i} / \Sigma S_{i}\right) \times 100$ (in \%), where $X_{i}$ is percentage of component ' $i$ ', $S_{i}$ - peak area of component ' $i$ ', and $\Sigma S_{i}-$ total sum area.

In situ diffuse-reflectance infrared spectroscopy (DRIFTS) was applied to characterize the surface of fresh and catalytically tested (used) samples by adsorption of CO and to follow changes of the surface species and intermediates during a real catalytic process in a $\mathrm{H}_{2} / \mathrm{CO}$ reaction mixture. Spectra were recorded on a Nicolet 6700 FTIR spectrometer (Thermo Electron Corporation, USA) 


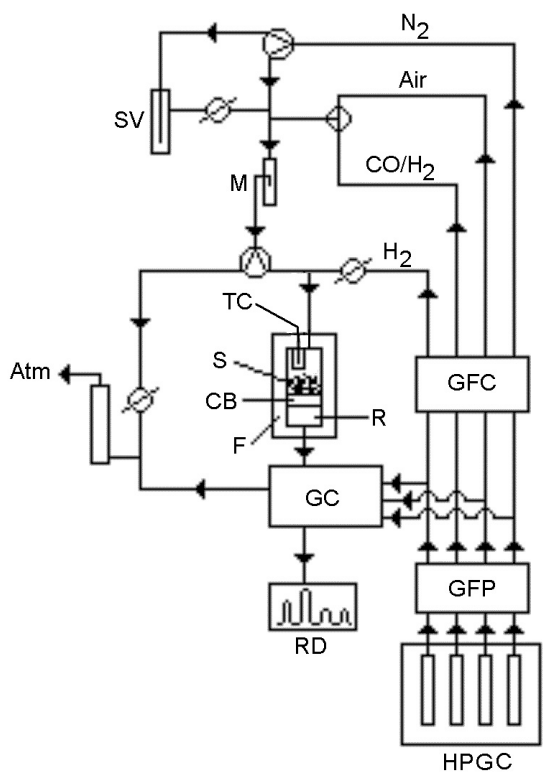

Scheme 1. Experimental setup for catalytic measurements. Designations: SV - saturating volume, $\mathrm{M}$ - mixer, TC thermocouple, S - studied sample, CB - catalyst bed, F furnace, $\mathrm{R}$ - glass reactor, $\mathrm{GC}$ - gas chromatograph, RD registering device, GFC - gas flow control unit, GFP - gas flow purification unit, HPGC - high-pressure cylinder gases.

equipped with Collector II accessory with High Temperature/ Vacuum/Gas flow chamber (Thermo Spectra-Tech, USA). $\mathrm{CaF}_{2}$ windows were used that limited the observed spectral range to $1111-4000 \mathrm{~cm}^{-1}$. All spectra were collected at 100 scans and $1.928 \mathrm{~cm}^{-1}$ data spacing. Thermal treatment in $\mathrm{Ar}$ flow was the first step applied to clean the surface of used sample $\left(40 \mathrm{ml} / \mathrm{min}, 1 \mathrm{~h}\right.$ at $\left.300{ }^{\circ} \mathrm{C}\right)$. The next step was reduction in $\mathrm{H}_{2}$ flow $\left(45 \mathrm{ml} / \mathrm{min}, 1 \mathrm{~h}\right.$ at $300^{\circ} \mathrm{C}$ ). Finally, $\mathrm{CO}$ hydrogenation was studied in a $\mathrm{H}_{2} / \mathrm{CO}(4 / 1)$ reaction mixture $\left(8 \mathrm{ml} / \mathrm{min}\right.$ ) from room temperature to $250{ }^{\circ} \mathrm{C}$. A temperature ramp of $10 \mathrm{deg} / \mathrm{min}$ was employed to attain selected reaction temperature level. An autotune temperature controller was used to regulate the temperature in the chamber. Spectra were recorded after $20 \mathrm{~min}$ regarding this period as sufficient to achieve a steady state of the reaction and constant gas phase composition in the measuring cell.

Temperature-programmed reduction (TPR) was carried out in a quartz reactor with $150 \mathrm{mg}$ charge of sample. The reducing agent was $10 \% \mathrm{H}_{2}$ in $\mathrm{Ar}$ at a flow rate of $25 \mathrm{ml} / \mathrm{min}$. Recorded TPR profiles were used for graphical calculation of the peak area at temperatures higher than that used for catalyst reduction. This area is proportional to the amount of unreduced metal (URMA for more active and URM for more selective sample) and can help in determining metal state in the studied samples. Determined areas were compared and the $R_{\text {URM }}$ ratio
$\mathrm{URM}_{\mathrm{A}} / \mathrm{URM}_{\mathrm{S}}$ was regarded as an additional feature to evaluate the role of unreduced metal.

X-ray photoelectron spectroscopy (XPS) analysis was carried out by means of ESCALAB MkII (VG Scientific) electron spectrometer at a base pressure in the analysis chamber of $5 \times 10^{-10} \mathrm{mbar}$ (during the measurement $1 \times 10^{-8}$ mbar) using Al Ka X-ray source with excitation energy $h v=$ $1486.6 \mathrm{eV}$. The pass energy of the hemispherical analyser was $20 \mathrm{eV}, 6 \mathrm{~mm}$ slit widths. The instrumental resolution measured as the full width at a half maximum of the $A g 3 d_{5 / 2}$ photoelectron peak was $1 \mathrm{eV}$. Depending on the support, the energy scale was corrected for electrostatic charging using the Al2p peak maximum at $74.4 \mathrm{eV}$. Data processing included subtraction of the X-ray satellites and Shirley-type background. ${ }^{[39]}$ The peak positions and areas were evaluated by a symmetrical Gaussian-Lorentzian curve fitting. The relative concentrations of the different chemical species were determined based on normalization of the peak areas to their photoionization cross-sections as calculated by Scofield. ${ }^{[40]}$

Experiments of $\mathrm{CO}$ temperature-programmed desorption (CO-TPD) were conducted by Setaram DSC 111 apparatus. The $\mathrm{CO}$ adsorption was carried out from a gas flow mixture of $10 \% \mathrm{CO}$ in $\mathrm{He}(20 \mathrm{ml} / \mathrm{min})$ at room temperature for $60 \mathrm{~min}$. TPD was implemented in He flow (20 $\mathrm{ml} / \mathrm{min}$ ) at a heating rate of $10 \mathrm{deg} / \mathrm{min}$ up to $700{ }^{\circ} \mathrm{C}$. Prior to the adsorption-desorption experiment the sample precursor was decomposed in accordance with the selected pretreatment procedure and then reduced sequentially at 300,400 , and $450{ }^{\circ} \mathrm{C}$ in the measuring cell.

\section{RESULTS AND DISCUSSION}

Comparative analysis of catalytic behaviour showed that depending on the medium during precursor treatment and reduction temperature the catalysts ranged in different rows of activity in the $\mathrm{CO}$ conversion and of selectivity to hydrocarbon $\left(\mathrm{CH}_{4}\right)$ formation. In case selectivity is evaluated by a $\mathrm{CH}_{4} / \mathrm{CO}_{2}$ ratio, a dependence on pretreatment mode was observed in the order reductive (red) $>>$ inert (inert) $\geq$ oxidative (ox). Independent of pretreatment mode, all samples demonstrated a decrease of the $\mathrm{CH}_{4} / \mathrm{CO}_{2}$ ratio upon increasing the reaction temperature. It is worth mentioning that a pronounced influence of reduction temperature was registered only with a catalyst sample prepared by oxidative pretreatment where the selectivity increased on increasing reduction temperature. Information about parameters and properties of the most active sample in $\mathrm{CO}$ conversion and that with high selectivity to $\mathrm{CH}_{4}$ at a reference reaction temperature of $300{ }^{\circ} \mathrm{C}$ as derived by different methods is shown in Table 1 and Figure 1. A catalyst sample of higher activity was formed using an oxidative pretreatment procedure (airflow) and reduction in hydrogen 
Table 1. Data derived by TPR, chemisorption and catalytic measurements for $(10 \% \mathrm{Co}+0.5 \% \mathrm{Pd}) / \mathrm{Al}_{2} \mathrm{O}_{3}$ catalysts.

\begin{tabular}{|c|c|c|c|c|c|c|c|c|c|}
\hline Catalyst type & Pretreatment & $\mathrm{T}_{\text {red, }}{ }^{\circ} \mathrm{C}$ & Co state & RURM & CO conv., $\%$ & $\mathrm{CH}_{4} / \mathrm{CO}_{2}$ & $\mathrm{D}_{\mathrm{H} 100 \mathrm{C}}, \%$ & $\mathrm{H}_{100 \mathrm{c}} / \mathrm{CO}_{\mathrm{s}}$ & $\mathrm{CO}_{\mathrm{s}} / \mathrm{CO}_{\mathrm{w}}$ \\
\hline Active & (ox) & 300 & $\mathrm{Co}^{0}, \mathrm{Co}^{n+}$ & & 33 & 6.3 & 3.4 & 3.4 & $\begin{array}{c}1.8 \\
(17.74 / 9.79)\end{array}$ \\
\hline Selective & (red) & $\begin{array}{c}(300) \\
400\end{array}$ & $\mathrm{Co}^{0}, \mathrm{Co}^{\mathrm{nt}}$ & 3.3 & 8 & 160 & 1 & 2.8 & $\begin{array}{c}0.5 \\
(6.03 / 13.07)\end{array}$ \\
\hline
\end{tabular}

RURM - unreduced metal ratio, $\mathrm{H}_{100 \mathrm{C}}$ - sample capacity for monolayer hydrogen adsorption measured at $100{ }^{\circ} \mathrm{C}$; $\mathrm{CO}_{\mathrm{w}}$ - sample capacity for reversible (weak) $\mathrm{CO}$ adsorption measured at room temperature; $\mathrm{CO}_{\mathrm{s}}$ - calculated sample capacity for irreversible (strong) $\mathrm{CO}$ adsorption; $\mathrm{D}_{\mathrm{H} 100 \mathrm{c}-}$ - metal dispersion based on $\mathrm{H}_{100 \mathrm{c}}$.

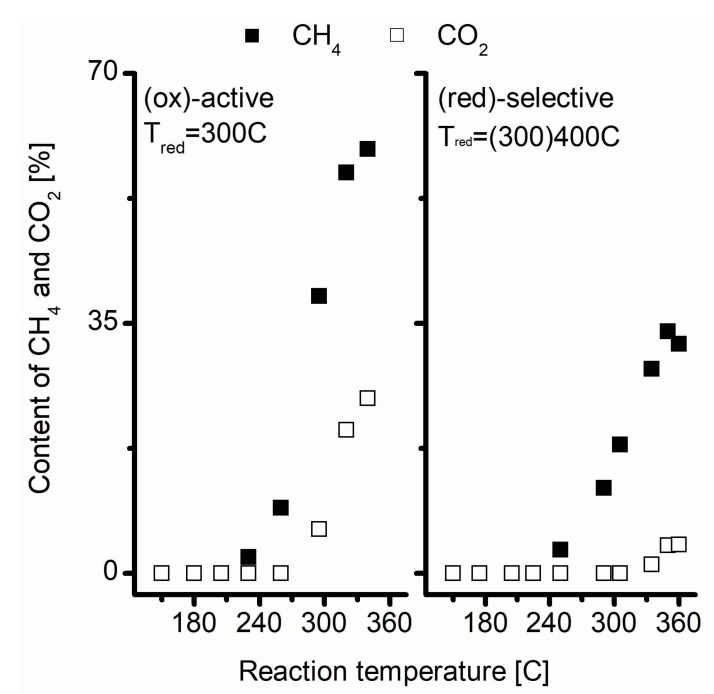

Figure 1. Catalytic behaviour of differently pretreated $(10 \% \mathrm{Co}+0.5 \% \mathrm{Pd}) / \mathrm{Al}_{2} \mathrm{O}_{3}$ samples.

flow at $300{ }^{\circ} \mathrm{C}$. It is denoted as $(10 \% \mathrm{Co}+0.5 \% \mathrm{Pd}) / \mathrm{Al}_{2} \mathrm{O}_{3}$ (ox). A catalyst sample of higher selectivity prepared by pretreatment in reductive atmosphere (hydrogen) is symbolised as $(10 \% \mathrm{Co}+0.5 \% \mathrm{Pd}) / \mathrm{Al}_{2} \mathrm{O}_{3}$ (red). It was reduced successively in hydrogen flow at 300 and $400{ }^{\circ} \mathrm{C}$ (Table 1 ).

It is known that $\mathrm{Al}_{2} \mathrm{O}_{3}$ is not very inert. It adsorbs $\mathrm{CO}$ and $\mathrm{CO}_{2}{ }^{[22,41]}$ In addition, chemical interactions could proceed with supported phase(s). Availability of free $\mathrm{OH}$ groups on the surface of oxide materials is of significance since they are considered catalytically active centres for reactions including $\mathrm{CO}$ and $\mathrm{CO}_{2} \cdot{ }^{[42]}$ It has been experimentally proved that surface hydroxyls participate in the formation of adsorbed carbonate-(like) species. 'Water-gas shift' route has been studied on alumina. ${ }^{[43]}$ It was shown that carbonate and formate structures could be formed via reaction between $\mathrm{CO}$ and surface $\mathrm{OH}$ groups to give $\mathrm{CO}_{2}$, which then reacts with $\mathrm{O}^{2-}$ or $\mathrm{OH}^{-}$. Bidentate and bicarbonate structures on alumina could be formed through interaction between $\mathrm{CO}$ and surface oxygen or a line defect with subsequent contact with $\mathrm{OH}$ groups from the surface. ${ }^{[41]}$ Bidentate carbonate and formate species are stable at $\mathrm{T} \leq 250^{\circ} \mathrm{C} .{ }^{[43]}$ Temperature-programmed desorption

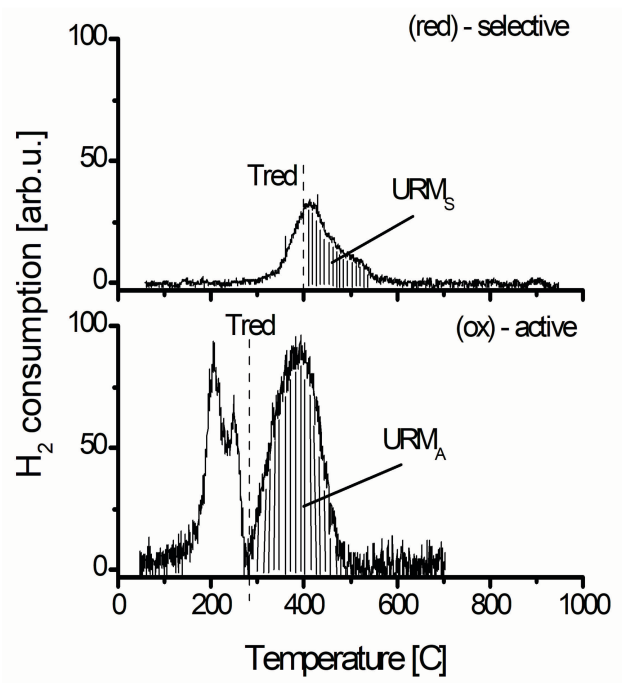

Figure 2. TPR profiles of differently pretreated $(10 \% \mathrm{Co}+0.5 \% \mathrm{Pd}) / \mathrm{Al}_{2} \mathrm{O}_{3}$ samples.

(TPD) of $\mathrm{CO}_{2}$ from alumina has shown that sites of moderate and strong adsorption, being the largest share, dominate on the surface and desorption occurs at $\mathrm{T} \geq 350^{\circ} \mathrm{C} .{ }^{[44]}$ There are numbers of studies in related literature demonstrating that the surface composition of the $\mathrm{Co} / \mathrm{Al}_{2} \mathrm{O}_{3}$ system is complex and only in rare cases contains one cobalt compound. [45-54]

A catalyst sample of higher activity was formed by pretreatment in air where the presence of $\mathrm{O}_{2}$ and $\mathrm{H}_{2} \mathrm{O}$ is presumed. The reduction was carried out at $300{ }^{\circ} \mathrm{C}$. A catalyst sample of higher selectivity was formed by pretreatment in reductive atmosphere (hydrogen flow) and reduced successively in $\mathrm{H}_{2}$ at 300 and $400^{\circ} \mathrm{C}$ for $1 \mathrm{~h}$ at each level (Table 1). The latter procedure supposes removal of a great amount of surface $\mathrm{OH}$ species. Thus, after reduction an active sample is assumed to preserve the $\mathrm{OH}$ coverage to a higher extent compared to the surface state of selective sample. As was mentioned above, during CO adsorption the hydroxyl coverage on the support favours formation of carbonate species.

Temperature-programmed reduction (TPR) profiles presented in Figure 2 outline the area related to unreduced 


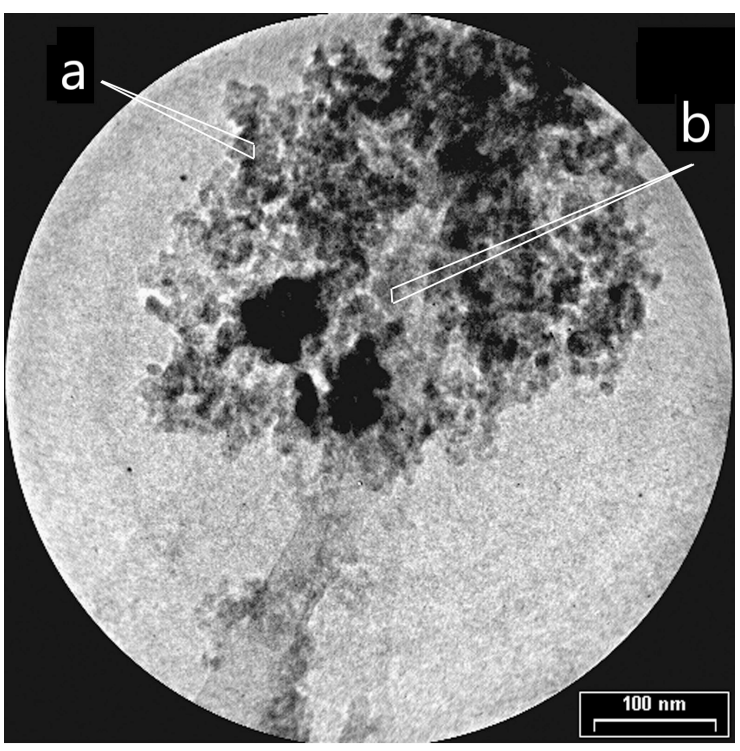
a $\mathrm{Al}-75 \% \mathrm{Co}-25 \% \mathrm{Pd}-0 \%$
b $\mathrm{Al}-25 \% \mathrm{Co}-26 \% \mathrm{Pd}-49 \%$

Figure 3. TEM image of $(10 \% \mathrm{Co}+0.5 \% \mathrm{Pd}) / \mathrm{Al}_{2} \mathrm{O}_{3}(\mathrm{red})$ selective catalyst with EDX analysis of selected regions.

metal in the studied materials. It can be stated that both samples worked in presence of reduced and ionic cobalt bearing in mind selected reduction temperature. As shown in Table 1 a 3.3-fold larger amount of oxidized cobalt in the active sample was found (RURM). A bigger quota of oxidized cobalt in the active sample is consistent with WGSR run at a higher extent leading to a higher $\mathrm{CO}_{2}$ content in the outlet gas flow. ${ }^{[55]}$

Despite differences in pretreatment, results obtained through chemisorption measurements showed an increase of strongly and weakly adsorbed CO species with rising reduction temperature for all synthesized samples. Since reversibly bonded CO desorbs readily at ambient conditions, strongly adsorbed $\mathrm{CO}_{\mathrm{s}}$ species is important for the chemistry of heterogeneous $\mathrm{CO}$ hydrogenation. According to pretreatment mode the amount of the latter on the samples varied in the order (inert) $>$ (ox) $>>$ (red). Change of the reduction temperature from 300 to $450{ }^{\circ} \mathrm{C}$ resulted in a decrease in the $\mathrm{H}_{100 \mathrm{c}} / \mathrm{CO}_{s}$ ratio. This effect was strongest for a (red)-type catalyst sample and less for (inert)-type entity. Analysis of chemisorption data showed higher metal dispersion and higher $\mathrm{H}_{100 \mathrm{c}} / \mathrm{CO}_{\mathrm{s}}$ and $\mathrm{CO}_{s} / \mathrm{CO}_{\mathrm{w}}$ ratios for the active sample. The selective sample had lower metal dispersion, a 2.9-fold lower amount of strongly adsorbed $\mathrm{CO}$ on the surface $\left(\mathrm{CO}_{s}(\mathrm{act}) / \mathrm{CO}_{s}(\mathrm{sel})=17.74 / 6.03\right)$ than the active sample, and a slightly higher amount ( 1.3 times) of reversibly adsorbed $\mathrm{CO}$ species $\left(\mathrm{CO}_{\mathrm{w}}(\mathrm{act}) / \mathrm{CO}_{\mathrm{w}}(\mathrm{sel})=\right.$ 9.79/13.07). The $\mathrm{H}_{100 \mathrm{c}} / \mathrm{CO}_{\mathrm{s}}$ ratio for the active sample, being higher than unity, was assigned to $\mathrm{CO}$ adsorption on metal particles presumably in bridge form indicating a greater portion of this species. Bridge-bonded $\mathrm{CO}$ species have a weaker $\mathrm{C}-\mathrm{O}$ bond that allows activation of $(10 \% \mathrm{Co}+0.5 \% \mathrm{Pd}) / \mathrm{Al}_{2} \mathrm{O}_{3}$ (ox) sample at a lower reaction temperature as has been frequently reported.[27-30,56] Obviously a large amount of irreversibly adsorbed $\mathrm{CO}$ on the surface of this sample $\left(\mathrm{CO}_{s} / \mathrm{CO}_{w}=1.8\right)$ favours not only the main reaction of $\mathrm{CO}$ hydrogenation but also that of $\mathrm{CO}_{2}$ synthesis. Pretreatment in hydrogen for $(10 \% \mathrm{Co}+0.5 \% \mathrm{Pd}) / \mathrm{Al}_{2} \mathrm{O}_{3}(\mathrm{red})$ catalyst sample followed by reduction at a higher temperature $\left(400^{\circ} \mathrm{C}\right)$ resulted in a low level of unreduced metal, enhanced formation of bimetallic particles, a less number of available pure Pd particles, and decreased metal dispersion related to a decreased number of multicentre adsorption sites (diminished $\mathrm{CO}_{\mathrm{s}} / \mathrm{CO}_{\mathrm{w}}$ ratio). Therefore, the prereduced sample acquired better selectivity to hydrocarbon formation due to increased possibility for alloy particle formation. Because of structure effect, high-coordinated adsorption sites are statistically much more vulnerable. The combination of metal atoms on the surface in the bimetallic particles provokes changes of the properties of the single constituents on the surface. Thus, the number of sites responsible for multicentre $\mathrm{CO}$ adsorption is decreased which indicates a significant structure effect in the bimetallic CoPd system. ${ }^{[57,58]}$

Figure 3 displays a TEM image of the selective sample after consecutive reduction at 300,400 , and $450^{\circ} \mathrm{C}$ to illustrate results from microscopic investigation. The TEM data revealed heterogeneous distribution in size of the supported metal particles. Metal agglomerates were observed in the samples. The outer contour and relative size allow supposing that the agglomerates consist of small crystallites with irregular form. EDX of sample selected parts, as demonstrated by marked diameter of the analysed regions, showed presence of regions containing only cobalt and areas enriched in palladium. However, by using TEM-EDX it was not possible to affirm formation of Co-Pd alloy.

$\mathrm{CO}$ desorption from $(10 \% \mathrm{Co}+1 \% \mathrm{Pd}) / \mathrm{Al}_{2} \mathrm{O}_{3}$ was studied by the method of TPD. Measurements were conducted by samples with higher concentration of Pd to enhance the amount of adsorbed/desorbed $\mathrm{CO}$ and ensure better discrimination of desorption from cobalt, palladium, and $\mathrm{Al}_{2} \mathrm{O}_{3}$. The adsorption of $\mathrm{CO}$ on the studied samples was accompanied by exothermic effect. The change in adsorption heat over time gradually decreased and did not stop completely within $60 \mathrm{~min}$. An impact of the pretreatment mode on the magnitude of the thermal effect was observed. It was minimal with a sample preliminary treated in reductive atmosphere. Samples pretreated in inert and oxidative medium gave rise to commensurable thermal effects that were four times higher than that registered with prereduced sample. This finding supposed 


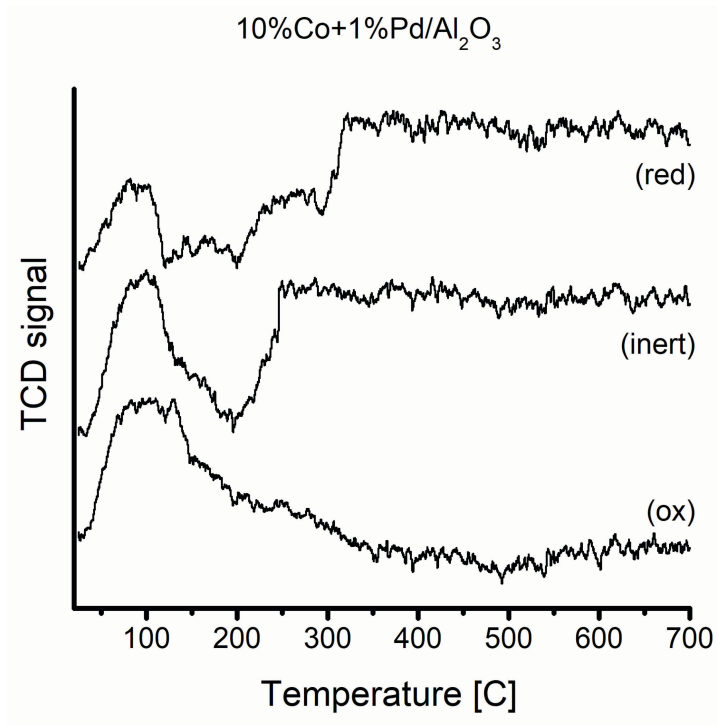

Figure 4. Carbon monoxide TPD profiles of $(10 \% \mathrm{Co}+1 \% \mathrm{Pd}) / \mathrm{Al}_{2} \mathrm{O}_{3}$ samples pretreated in different gas medium and reduced sequentially at 300,400 , and $450{ }^{\circ} \mathrm{C}$.

presence of smaller particles in (ox)-type sample. Particle surface in this case is energetically unsaturated, which makes it more active during $\mathrm{CO}$ adsorption.

Desorption process was accompanied by very weak endothermal effects. CO-TPD from the catalyst samples took place in the interval of $20-200{ }^{\circ} \mathrm{C}$ with maxima about $100{ }^{\circ} \mathrm{C}$ and shoulders around $163{ }^{\circ} \mathrm{C}$ (Figure 4). Within 200-700 ${ }^{\circ} \mathrm{C}$, no clearly pronounced maxima (plateaux) were observed in a wide temperature interval. Desorbed amount of $\mathrm{CO}$ was very low and close to detection limit of the thermal conductivity detector (TCD) sensitivity. Thus, a clear distinction of different $\mathrm{CO}$ species was not possible. However, we claim that the linearly and bridge-bonded CO species were desorbed in the low temperature interval whereas carbonate/carboxylate structures were desorbed in the high temperature range in agreement with reference data. ${ }^{[43,44]}$

X-ray photoelectron spectroscopy study was conducted ex situ with all samples after completed catalytic test. The latter consisted of consecutive reduction at 300 ,
400 , and $450{ }^{\circ} \mathrm{C}$ followed by catalytic activity measurements at each level of reduction. $\mathrm{Co}^{2+}$ and $\mathrm{Co}^{3+}$ ions were registered on the surface. Their presence was essential due to the 'ex-situ' measurements, which allowed adsorption of oxygen and oxidation of the particle surface without penetration into the bulk. ${ }^{[59,60]}$

The following orders of dependences were found: (i) decreased amount of surface $\mathrm{Pd}$ (red) $>$ (inert) $\geq$ (ox); (ii) decreased total amount of $\mathrm{Co}^{\mathrm{n}+}($ red $)>(\mathrm{ox})>$ (inert); and (iii) change of the $\mathrm{Co}^{2+} / \mathrm{Co}^{3+}$ ratio to $6: 2.6: 4.6$ for (red):(ox):(inert), respectively. Data presented in Table 2 reveal that the surface of the selective sample is enriched in cobalt and palladium. Conclusions based on XPS data concerning cobalt are indirect, however, the results presume a higher extent of cobalt reduction in (red)-type sample. The XPS study found carbonate species residing on the surface of the samples, the amount being dependent on pretreatment mode in the order (red) $>$ (ox) $>$ (inert). This result is consistent with existence of stronger adsorption sites for the carbonate-like species on the selective sample. ${ }^{[61]}$

Figure 5 shows in situ DRIFTS spectra recorded during $\mathrm{CO}$ hydrogenation in flow conditions. The doublet centred at $2142 \mathrm{~cm}^{-1}$ consists of characteristic bands of gaseous $\mathrm{CO}$ which overlap those of $\mathrm{CO}$ species adsorbed on metal ions within the region $2100-2200 \mathrm{~cm}^{-1}$. The bands of $\mathrm{CO}$ adsorbed on metal atoms (Co, Pd) appeared in the range of $2100-1700 \mathrm{~cm}^{-1}$. They were ascribed as follows: about $1767 \mathrm{~cm}^{-1}$ - bridge-bonded $\mathrm{CO}$ on $\mathrm{Co}^{0} / \mathrm{C}=\mathrm{O}$ vibrations from various complex oxygenate species, $1965 \mathrm{~cm}^{-1}$ bridge-bonded $\mathrm{CO}$ on $\mathrm{Pd}^{0}$ and/or $\mathrm{Co}^{0} ; 1990 \mathrm{~cm}^{-1}$ - bridgebonded $\mathrm{CO}$ on $\mathrm{Pd}^{0}$ and/or linear $\mathrm{CO}$ species on $\mathrm{Co}^{0}$; several superimposed bands in the $2000-2015 \mathrm{~cm}^{-1}$ region linearly bonded $\mathrm{CO}$ on $\mathrm{Co}^{0} ; 2032 / 40 \mathrm{~cm}^{-1}$ - linear $\mathrm{CO}$ on $\mathrm{Co}^{0}$ and/or $\left.\mathrm{Co}^{\delta+}\right) ; 2063 \mathrm{~cm}^{-1}$ - hydrocarbonyl species ( $\mathrm{H}-\mathrm{Co}-\mathrm{CO}) .[6,25,30,56,62-70]$ Registration of many bands of adsorbed CO shows a great diversity of adsorption sites which is due to differences in coordination and electronic state of the surface atoms in the metal particles.

Figure 6 shows spectra of selective and active catalyst samples in a reaction mixture recorded at room temperature before and after spectral measurements in

Table 2. Ex situ XPS data on ( $10 \% \mathrm{Co}+0.5 \% \mathrm{Pd}) / \mathrm{Al}_{2} \mathrm{O}_{3}$ catalyst samples.

\begin{tabular}{|c|c|c|c|c|c|c|c|c|c|c|c|c|c|}
\hline \multirow{3}{*}{$\begin{array}{c}\text { Element/ } \\
\text { Sample } \\
\text { type }\end{array}$} & \multicolumn{3}{|c|}{ C1s } & \multicolumn{2}{|c|}{ O1s } & \multicolumn{2}{|c|}{$A \mid 2 p$} & \multicolumn{2}{|c|}{$\mathrm{Pd} 3 \mathrm{~d}\left(\mathrm{Pd}^{0}\right)$} & \multicolumn{4}{|c|}{$\operatorname{Co} 2 p_{1 / 2}$} \\
\hline & \multirow[b]{2}{*}{$\mathrm{eV}$} & \multirow[b]{2}{*}{ at. $\%$} & \multirow{2}{*}{$\mathrm{CO}_{3} \%$} & \multirow[b]{2}{*}{$\mathrm{eV}$} & \multirow{2}{*}{ at. \% } & \multirow{2}{*}{$\mathrm{eV}$} & \multirow{2}{*}{ at. \% } & \multirow[b]{2}{*}{$\mathrm{eV}$} & \multirow{2}{*}{ at. $\%$} & \multicolumn{2}{|c|}{$\mathrm{Co}^{2+}$} & \multicolumn{2}{|c|}{$\mathrm{Co}^{3+}$} \\
\hline & & & & & & & & & & $\mathrm{eV}$ & at. \% & $\mathrm{eV}$ & at. $\%$ \\
\hline (red) & 286.0 & 3.54 & $\sim 50$ & 531.3 & 55.60 & 74.4 & 37.31 & 336.0 & 0.12 & 797.2 & $\begin{array}{c}3.05 \\
(86 \%)^{*}\end{array}$ & 795.5 & $\begin{array}{c}0.5 \\
(14 \%)^{*}\end{array}$ \\
\hline (ox) & 284.5 & 3.15 & $\sim 40$ & 531.3 & 54.96 & 74.4 & 38.92 & 336.1 & 0.06 & 797.1 & $\begin{array}{c}1.06 \\
(72 \%)^{*}\end{array}$ & 795.5 & $\begin{array}{c}0.6 \\
(28 \%)^{*}\end{array}$ \\
\hline
\end{tabular}

* - percentage of cobalt ions on the surface. 
(A)

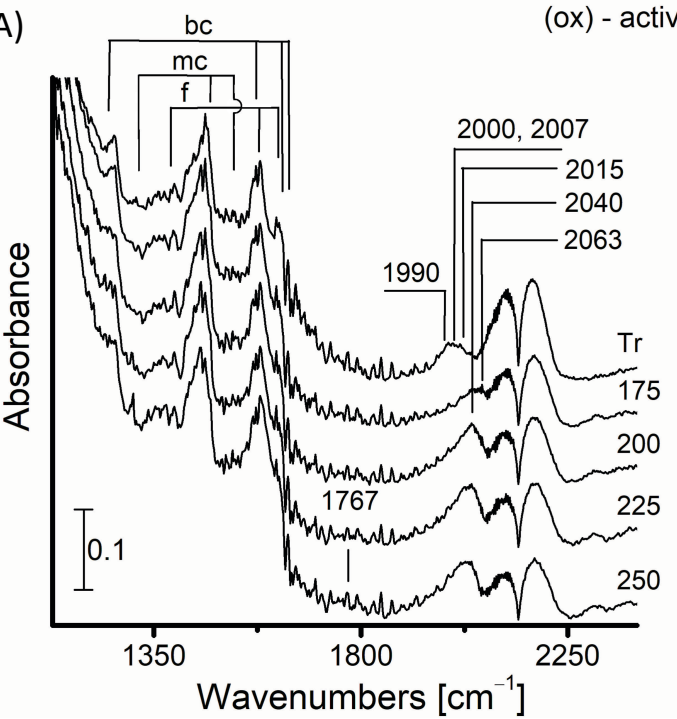

(B)

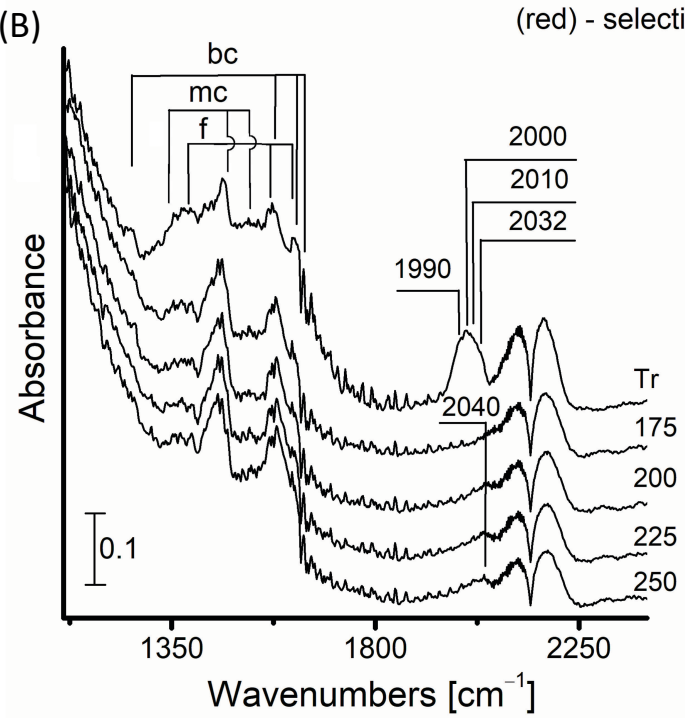

Figure 5. In situ DRIFT spectra during $\mathrm{CO}$ hydrogenation on $(10 \% \mathrm{Co}+0.5 \% \mathrm{Pd}) / \mathrm{Al}_{2} \mathrm{O}_{3}$ active $(\mathrm{A})$ and selective $(\mathrm{B})$ samples. Symbols: $\mathrm{mc}$ - monodentate carbonate; $\mathrm{bc}$ - bidentate carbonate; $\mathrm{f}$ - formate species.

the temperature range of $56-250{ }^{\circ} \mathrm{C}$. With both systems, the more intense $\mathrm{CO}$ gas bands were very slightly decreased after the catalytic test. As the results show, taking into account that the $\mathrm{CO}$ species on $\mathrm{Co}^{1+}$ and $\mathrm{Co}^{2+}$ give rise to bands in this region, a very small part of these metal ions occurs unreduced after preceding catalytic activity test. Bands at about $2000 \mathrm{~cm}^{-1}$ with the selective sample show almost equal intensity before and after IR experiments, which is explained by achieving a stable catalyst properties/behaviour. With the active catalyst a shift of the broad band at about $1990 \mathrm{~cm}^{-1}$ to $2040 \mathrm{~cm}^{-1}$ with increased intensity was observed. This result is assigned to a catalyst surface enriched in sites for linearly bonded $\mathrm{CO}$ species especially that as $\mathrm{CO}-\mathrm{Co}^{\delta+}$. In addition, this finding shows that despite preliminary catalytic activity test with the active sample there occurred still some amount of relatively stable unreduced cobalt phase in close proximity to support and/or small metal particles with a surface that can be readily oxidized while exposed to water and further reduced during the catalytic process. In the literature, $\mathrm{Co}^{\delta+}$ state is assigned to impact of the oxygen from the support on interface cobalt atoms leading to a partial positive charge on the latter ${ }^{[71]}$ and correlate with a higher share of surface metal atoms of small particles that are in contact with alumina. Bearing in mind discussed above, TPR and dispersion data, the in situ IR study shows that large metal particles have essential contribution to selectivity.

During static DRIFTS experiments, reaction mixture flow was admitted to the catalyst at room temperature and after 15 minutes, the cell was isolated. For a period of 25 minutes, the spectra showed changes in the bands of $\mathrm{CO}$ adsorbed on cobalt and palladium atoms, namely, at about 1995 and $2001 \mathrm{~cm}^{-1}$ with 'selective' and 'active' sample, respectively. In the spectra of selective sample, the band decreased in intensity with time, but the band of the active sample disappeared. The result is in line with a higher activity of the $(10 \% \mathrm{Co}+0.5 \% \mathrm{Pd}) / \mathrm{Al}_{2} \mathrm{O}_{3}$ (ox) catalyst due to higher metal dispersion which in turn allows a rapid formation of intermediates with facilitated transfer of the latter to the support.

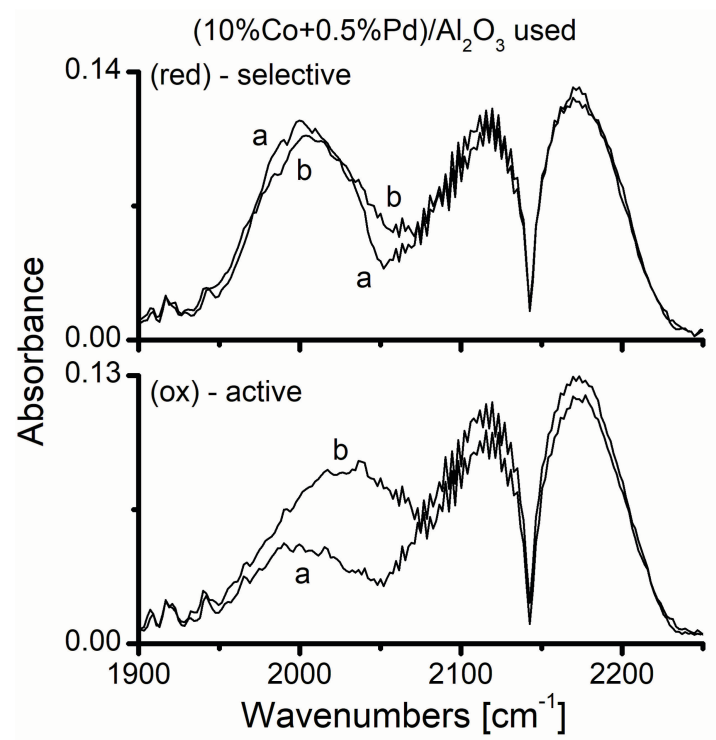

Figure 6. DRIFT spectra of $(10 \% \mathrm{Co}+0.5 \% \mathrm{Pd}) / \mathrm{Al}_{2} \mathrm{O}_{3}(\mathrm{ox})$ and $(10 \% \mathrm{Co}+0.5 \% \mathrm{Pd}) / \mathrm{Al}_{2} \mathrm{O}_{3}$ (red) samples in a $\mathrm{CO} / \mathrm{H}_{2}(1 / 4)$ reaction mixture at room temperature: before (a) and after (b) in situ spectral study up to $250^{\circ} \mathrm{C}$. 
During in situ IR study of CO hydrogenation from room temperature to $125{ }^{\circ} \mathrm{C}$, changes in the bands in the region $1840-2020 \mathrm{~cm}^{-1}$ were different for the active and selective samples (these spectra are not shown in Figure 5). A higher stability of the adsorbed $\mathrm{CO}$ species was observed with the selective sample since the band did not shift but decreased in intensity with temperature and disappeared at $86^{\circ} \mathrm{C}$. With the active catalyst, no bands for linear species were observed already at $56{ }^{\circ} \mathrm{C}$. These changes were accompanied by slightly increased intensity of the bands in the range characteristic of bridge-bonded species. Such a transformation was observed and explained by the hypothesis that co-adsorbed hydrogen provokes a shift of linear $\mathrm{CO}$ species to a neighbour atom by forming a bridge

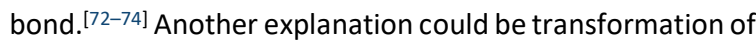
part of the $\mathrm{CO}$ species in $\mathrm{COH}_{x}$ intermediates. Thus, the changes in this wavenumber region and temperature interval confirmed an increased activity of the (ox)-type sample due to domination of bridge-bonded $\mathrm{CO}$ species in which the $\mathrm{C}-\mathrm{O}$ bond was easier to split thus favouring hydrogenation at a lower temperature. ${ }^{[27]}$

A rising band at about $2040 \mathrm{~cm}^{-1}$ that increased in intensity with temperature in the interval of $175-250^{\circ} \mathrm{C}$ (Figure 5) is most probably due to appearance of cobalt ions $\left(\mathrm{Co}^{\delta+}\right)$ in close vicinity of $\mathrm{Al}_{2} \mathrm{O}_{3} \cdot{ }^{[55,69]}$ These entities originate from partial oxidation of the surface Co atoms by water molecules and/or reduction of residual Co oxide phases and Co ions on the support with formation of new adsorption centres. The process was much more pronounced on the active catalyst having in mind the results displayed in Figures 5 and 6 . Contribution of cobalt hydrocarbonyl species to band broadening and intensity increase could not be excluded. The spectra show a significant stability of the $\mathrm{CO}$ adsorption on these sites. CO firmly detained on the surface as irreversibly adsorbed species is considered a condition that favours hydrogenation to methane. ${ }^{[55,68]}$

Bands characteristic of hydrocarbon species were also distinguished in the spectra by vibrations of methyl $\left(\mathrm{CH}_{3}\right)$ groups at 1324/80/95, 1420/52, $2957 \mathrm{~cm}^{-1}$; methylene $\left(\mathrm{CH}_{2}\right)$ groups at $1472,2850 / 51,2923 / 26 \mathrm{~cm}^{-1}$; and methine $(\mathrm{CH})$ groups at $1356 \mathrm{~cm}^{-1} \cdot{ }^{[28,64]}$ An increase of intensity was observed at a reaction temperature over $175^{\circ} \mathrm{C}$ and this mostly concerned the stretching vibrations of $\mathrm{CH}_{2}$ groups at $2923 / 26 \mathrm{~cm}^{-1}$. Synthesis of target methane reaction product $\left(1305 \text { and } 3016 \mathrm{~cm}^{-1}\right)^{[75]}$ became perceptible in the spectra of $(10 \% \mathrm{Co}+0.5 \% \mathrm{Pd}) / \mathrm{Al}_{2} \mathrm{O}_{3}$ (ox) at $150{ }^{\circ} \mathrm{C}$ and $(10 \% \mathrm{Co}+0.5 \% \mathrm{Pd}) / \mathrm{Al}_{2} \mathrm{O}_{3}$ (red) at $225{ }^{\circ} \mathrm{C}$. The respective bands increased in intensity with increasing temperature. It is worth to note that well resolved bands of high enough intensity characteristic of hydrocarbon species were recorded at room temperature with active catalyst sample. The samples were prepared for in situ DRIFTS studies following the same procedure and conditions: $\mathrm{Ar}$ flow at $300{ }^{\circ} \mathrm{C}$ for 30 min followed by reduction in $\mathrm{H}_{2}$ flow at $300{ }^{\circ} \mathrm{C}$ for $1 \mathrm{~h}$. From one hand, this peculiarity gives evidence for enhanced activity of (ox)-type sample but on the other hand - for strong adsorption of $\mathrm{CH}_{\mathrm{x}}$ species. ${ }^{[76,77]}$

As was mentioned above the band at about 2040 $\mathrm{cm}^{-1}$ increased in intensity with temperature (Figure 5). It is assigned to linearly adsorbed $\mathrm{CO}$ on $\mathrm{Co}^{\delta+}$. It is known from the literature that this adsorbed species is associatively activated, manifests low ability for dissociation, and is assigned to a reinforced contact between cobalt and support. ${ }^{[69,78]}$ It is also known that associatively bonded CO is hardly hydrogenated. ${ }^{[6,79]}$

As aforementioned, upon CO adsorption the hydroxyl coverage on the support favours formation of formate and carbonate species. These species are also formed through $\mathrm{CO}$ spillover from the metal particles away to the support. A close contact between metal and the support could facilitate the interaction of $\mathrm{CO}$ adsorbed on $\mathrm{Co}^{\delta+}$ with oxygen from the support resulting in formation of carbonate-(like) species and $\mathrm{CO}_{2}$. Surface enrichment in $\mathrm{Co}^{\delta+}$ could also contribute to formation of $\mathrm{CO}_{2}$. In the spectra of active sample the following bands due to carbonate-like species were registered: bidentate $(1243 / 56 / 64,1566 / 80$, $\left.1622 / 40 \mathrm{~cm}^{-1}\right)$; monodentate $\left(1324,1472,1525 \mathrm{~cm}^{-1}\right)$; and formate $\left(1370 / 95,1566 / 80,1622 \mathrm{~cm}^{-1}\right.$ ) (Figure 5A).[22,64] None of these bands changed on increasing the reaction temperature to $225^{\circ} \mathrm{C}$, however, at $250^{\circ} \mathrm{C}$ their intensity was slightly increased. The same surface species were recorded on the surface of selective catalyst sample by the following sets of bands: monodentate $(1320 / 56 / 75,1472$, $\left.1522 \mathrm{~cm}^{-1}\right)$, bidentate $\left(1255,1566 / 73 / 80,1616,1640 \mathrm{~cm}^{-1}\right)$, and formate $\left(1356 / 75 / 90,1566 / 73 / 80,1616 \mathrm{~cm}^{-1}\right.$ ) (Figure 5B). ${ }^{[22,64]}$ Unlike the spectral changes with active sample, the bands characteristic of formates and monodentate carbonates increased in intensity with increasing temperature. Enhanced absorption in this region was found at $250{ }^{\circ} \mathrm{C}$ but the bands due to bidentate carbonate species slightly decreased in intensity. Formate species was relatively stable in the selected range of reaction temperature in agreement with increased/preserved intensity of the characteristic bands. Analysis of TPD results and IR data indicates that carbonate-(like) species on a (red)-type sample is suggested to desorb as bidentate carbonate within the interval $200-300{ }^{\circ} \mathrm{C}$. This surface species is classified as weakly held carbonate ${ }^{[41]}$ whereas desorption of formate and monodentate carbonate species takes place at higher temperatures resulting in a plateau in the TPD profile. The results of TPD, XPS, and in situ DRIFTS suppose existence of sites for strong adsorption of these intermediates on the sample surface. Thus, $\mathrm{CO}_{2}$ formation was suppressed, which identified the $(10 \% \mathrm{Co}+0.5 \% \mathrm{Pd}) / \mathrm{Al}_{2} \mathrm{O}_{3}$ (red) sample as more selective. 
Comparative analysis based on the spectral features of both samples during $\mathrm{CO}$ hydrogenation showed that the bidentate carbonate species was more abundant on active sample since a higher intensity of the respective band was observed at all studied temperatures. The bands of gas phase $\mathrm{CO}_{2}$ over the active catalyst sample $\left(2306 \mathrm{~cm}^{-1}{ }^{[64]}\right)$ were also more intense. It can be concluded that $\mathrm{CO}_{2}$ was produced by decomposition of bidentate carbonate species bearing in mind that on the active sample the intensity of the bands in the carbonate region remained constant, i.e. surface species concentration was preserved and band intensity of the bidentate carbonate species was decreased. Moreover, adsorption sites of moderate strength can be assigned responsible for this transformation.

Grenoble et al. ${ }^{[80]}$ have shown that $\mathrm{Al}_{2} \mathrm{O}_{3}, \mathrm{Pd} / \mathrm{Al}_{2} \mathrm{O}_{3}$, and $\mathrm{Co} / \mathrm{Al}_{2} \mathrm{O}_{3}$ are active in WGSR. Having in mind that an active sample in this study contains relatively more monometallic $\mathrm{Co}$ and $\mathrm{Pd}$ particles, their ability to activate WGSR should not be excluded as additional contribution to $\mathrm{CO}_{2}$ production. Therefore, it can be concluded that an active sample is characterized by a greater number of monometallic $\mathrm{Co}$ and $\mathrm{Pd}$ particles, a greater quota of bridged-bonded $\mathrm{CO}$ species on the metal particles, abundance of strongly bonded $\mathrm{CO}$ species, many cobalt ions, a stable $\mathrm{OH}$ group coverage preserved to a high extent after reduction at $300{ }^{\circ} \mathrm{C}$, existence of medium-strength sites on the support for carbonate(s) adsorption, and available sites of moderate strength for monodentate carbonate and formate species adsorption on the support. $\mathrm{CO}_{2}$ production on active catalyst samples was facilitated by all these factors.

The catalyst of better selectivity to methane formation, and other hydrocarbons accordingly, was obtained by stepwise pretreatment in $\mathrm{H}_{2}$ followed by reduction at higher temperatures. This pretreatment mode resulted in a low level of unreduced metal (cobalt), a greater number of bimetallic particles, a low (if any) amount of monometallic Pd particles, decreased metal dispersion, partial removal of surface $\mathrm{OH}$ species, a greater share of sites for carbonate species formation on the surface, and existence of sites for stronger adsorption of the latter species. It is known that $\mathrm{CO}_{2}$ desorbs from $\mathrm{Pd} / \mathrm{Al}_{2} \mathrm{O}_{3}$ at about 130 and $500{ }^{\circ} \mathrm{C} .{ }^{[81]}$ Consequently, a decreased rate of carbonate destruction with evolution of $\mathrm{CO}_{2}$ should contribute to diminishing the WGSR rate and thus the adsorbed $\mathrm{CO}$ is being spent mainly for $\mathrm{CH}_{4}$ formation.

\section{CONCLUSIONS}

Comparative data analysis of a number of methods showed successful synthesis of $(10 \% \mathrm{Co}+0.5 \% \mathrm{Pd}) / \mathrm{Al}_{2} \mathrm{O}_{3}$ catalyst system by deposition of metal salts from nitrate solution on alumina support. Based on preparation and application of different sets of precursor pretreatment and reduction highly active samples were prepared for $\mathrm{CO}$ conversion to $\mathrm{CH}_{4}$ and $\mathrm{CO}_{2}$ or more selective entities giving higher yields of methane and higher/other hydrocarbons.

The activation procedure of selective type catalyst supposed higher probability about bimetallic particle formation and larger particle size, which favoured methane formation. Another special feature of this type of samples was lower share of irreversibly adsorbed $\mathrm{CO}$ and firmly adsorbed carbonate and formate species. However, a higher selectivity was realized at low conversion. The ratios of adsorbed hydrogen to strongly adsorbed $\mathrm{CO}$ and of strongly to weakly adsorbed CO species seemed to be important criteria for determining catalyst quality along with supported metal state, amount of unreduced ions, bimetallic particle formation, and ability of alumina for $\mathrm{CO}$ and $\mathrm{CO}_{2}$ adsorption.

Acknowledgements. Financial support by Bulgarian National Science Fund through contract KP-06-H29-9/14.12.2018 is gratefully acknowledged. Research equipment of distributed research infrastructure INFRAMAT (part of Bulgarian national roadmap for research infrastructures) supported by Bulgarian Ministry of Education and Science under contract D01-155/28.08.2018 was used in this investigation. English language text editing by Assoc. Prof. Ch. Bonev is greatly acknowledged.

\section{REFERENCES}

[1] P. T. Anastas, M. M. Kirchhoff, T. C. Williamson, Appl. Catal. A: Gen. 2001, 221, 3-13.

https://doi.org/10.1016/S0926-860X(01)00793-1

[2] B. H. Davis, E. Iglesia, Technology Development for Iron and Cobalt Fischer-Tropsch Catalysts, Final Technical Report DE-FC26-98FT40308, University of California at Berkeley \& University of Kentucky Research Foundation, 2002.

[3] Z. Gholami, Z. Tišler, V. Rubáš, Catal. Rev. Sci. Eng. 2020, 62, 1-84.

https://doi.org/10.1080/01614940.2020.1762367

[4] M. Arsalanfar, A. A. Mirzaei, H. R. Bozorgzadeh, A. Samimi, Phys. Chem. Res. 2014, 2, 179-201.

[5] W. Ma, G. Jacobs, R. A. Keogh, D. B. Bukur, B. H. Davis, Appl. Catal. A: Gen. 2020, 437-438, 1-9. https://doi.org/10.1016/j.apcata.2012.05.037

[6] J. J. C. Geerling, M. C. Zonnevylle, C. P. M. de Groot, Surf. Sci. 1991, 241, 302-314 and 315-324. https://doi.org/10.1016/0039-6028(91)90091-6

[7] T. Nowitzki, A. F. Carlsson, O. Martyanov, M. Naschitzki, V. Zielasek, T. Risse, M. Schmal, H.-J. Freund, M. Baumer, J. Phys. Chem. C 2007, 111, 8566-8572. https://doi.org/10.1021/jp066796r 
[8] W. Chen, T. Lin, Y. Dai, Y. An, F. Yu, L. Zhong, S. Li, Y. Sun, Catal. Today 2018, 311, 8-22.

https://doi.org/10.1016/j.cattod.2017.09.019

[9] A. Rabo, A. Risch, M. Poutsma, J. Catal. 1978, 53, 295311. https://doi.org/10.1016/0021-9517(78)90102-1

[10] J. P. Hinderman, G. J. Hutchings, A. Kiennemann, Catal. Rev. Sci. Eng. 1993, 35, 1.

https://doi.org/10.1080/01614949308013907

[11] A.S. Lysitsin, A.V. Golovin, V. L. Kuznetsov, Yu. I. Ermakov, J. Catal. 1985, 95, 527.

[12] M. A. Vannice, J. Catal. 1975, 37, 449 and 462. https://doi.org/10.1016/0021-9517(75)90182-7

[13] M. L. Poutsma, L. F. Elek, D. A. Ibaria, A. P. Risch, J. A. Rabo, J. Catal. 1978, 52, 157. https://doi.org/10.1016/0021-9517(78)90131-8

[14] F. Fajula, R. G. Anthony, J. H. Lunsfort, J. Catal. 1982, 73, 237. https://doi.org/10.1016/0021-9517(82)90098-7

[15] S. Sun, K. Fujimoto, Y. Yoneyama, N. Tsubaki, Fuel 2002, 81, 1583.

https://doi.org/10.1016/\$0016-2361(02)00090-X

[16] F. B. Noronha, M. Schmal, B. Moraweck, P. Delichere, M. Brun, F. Villain, R. Frety, J. Phys. Chem. B 2000, 104, 5478-5485.

https://doi.org/10.1021/jp992777o

[17] T. Mallat, S. Szabo, J. Petro, S. Mendioroz, M. A. Falgado, Appl. Catal. 1989, 53, 29. https://doi.org/10.1016/S0166-9834(00)80007-X

[18] J. Szanyi, J. H. Kwak, Phys. Chem. Chem. Phys. 2014, 16, 15117-15125. https://doi.org/10.1039/C4CP00616J

[19] X. Zhao, Y. Yue, Y. Zhang, W. Hua, Z. Gao, Catal. Lett. 2003, 89, 41-47. https://doi.org/10.1023/A:1024711224361

[20] C. Weilach, C. Spiel, K. Föttinger, G. Rupprechter, Surf. Sci. 2011, 605, 1503-1509.

https://doi.org/10.1016/j.susc.2011.05.025

[21] B. Singh, J. Patial, P. Sharma, S. Chandra, S. Maity, N. Lingaiah, Indian J. Chem. Technol. 2010, 17, 446-450.

[22] A. Paredes-Nunez, D. Lorito, N. Guilhaume, C. Mirodatos, Y. Schuurman, F. C. Meunier, Catal. Today 2015, 242, 178-183.

https://doi.org/10.1016/j.cattod.2014.04.033

[23] S. Zheng, Y. Liu, J. Li, B. Shi, Appl. Catal. A: Gen. 2007, 330, 63.

https://doi.org/10.1016/j.apcata.2007.07.010

[24] N. Kumar, M. L. Smith, J. J. Spivey, J. Catal. 2012, 289, 218-226.

https://doi.org/10.1016/j.jcat.2012.02.011

[25] D. Song, J. Li, Q. Cai, J. Phys. Chem. C 2007, 111, 18970. https://doi.org/10.1021/jp0751357

[26] H. Arakawa, K. Takeuchi, T. Matsuzaki, Y. Sugi, J. Jpn. Pet. Inst. 1988, 31, 335.
[27] F. Morales, E. de Smit, F. M. de Groot, T. Visser, B. M. Wechuysen, J. Catal. 2007, 246, 91.

[28] H. Xiong, Y. Zhang, K. Liew, J. Li, Fuel Process. Technol. 2009, 90, 237-246.

https://doi.org/10.1016/j.fuproc.2008.08.014

[29] H. Xiong, Y. Zhang, K. Liew, J. Li, J. Mol. Catal. A: Chem. 2008, 295, 68-76.

https://doi.org/10.1016/j.molcata.2008.08.017

[30] N. Tsubaki, S. Sun, K. Fujimoto, J. Catal. 2001, 199, 236. https://doi.org/10.1006/jcat.2001.3163

[31] Z. Qi, L. Chen, S. Zhang, J. Su, G. A. Somorjai, Appl. Catal. A: Gen. 2020, 117701.

https://doi.org/10.1016/j.apcata.2020.117701

[32] C. J. Weststrate, P. van Helden, J. van de Loosdrecht, J. W. Niemantsverdriet, Surf. Sci. 2016, 648, 60-66. https://doi.org/10.1016/j.susc.2015.10.050

[33] A. A. Mirzaei, B. Shirzadi, H. Atashi, M. Mansouri, J. Ind. Eng. Chem. 2012, 18, 1515-1521. https://doi.org/10.1016/j.jiec.2012.02.013

[34] M. G. Shopska, I. Zh. Shtereva, H. G. Kolev, K. I. Aleksieva, S. Zh. Todorova, G. B. Kadinov, Bulg. Chem. Commun. 2020, 52, 320-327.

[35] P. C. Aben, J. Catal. 1968, 10, 224. https://doi.org/10.1016/S0021-9517(68)80002-8

[36] R. C. Reuel, C. H. Bartholomew, J. Catal. 1984, 85, 63. https://doi.org/10.1016/0021-9517(84)90110-6

[37] J. M. Zowtiak, C. H. Bartholomew, J. Catal. 1983, 83, 107. https://doi.org/10.1016/0021-9517(83)90034-9

[38] J. R. Anderson, Structure of metallic catalysts, Mir, Moscow, 1978 (in Russian).

[39] D. Shirley, Phys. Rev. B 1972, 5, 4709-4714. https://doi.org/10.1103/PhysRevB.5.4709

[40] J. H. Scofield, J. Electron Spectrosc. Relat. Phenom. 1976, 8, 129.

https://doi.org/10.1016/0368-2048(76)80015-1

[41] J. Szanyi, J. H. Kwak, Phys. Chem. Chem. Phys. 2014, 16, 15117-15125.

https://doi.org/10.1039/C4CP00616J

[42] X. Zhao, Y. Yue, Y. Zhang, W. Hua, Z. Gao, Catal. Lett. 2003, 89, 41-47. https://doi.org/10.1023/A:1024711224361

[43] C. Weilach, C. Spiel, K. Föttinger, G. Rupprechter, Surf. Sci. 2011, 605, 1503-1509. https://doi.org/10.1016/j.susc.2011.05.025

[44] B. Singh, J. Patial, P. Sharma, S. Chandra, S. Maity, N. Lingaiah, Indian J. Chem. Technol. 2010, 17, 446-450.

[45] A. L. Lapidus, A. Yu. Krilova, M. P. Kapur, E. V. Leongardt, A. B. Fasman, S. D. Mikhailenko, Russ. Chem. Bull. 1992, 41, 45-48. https://doi.org/10.1007/BF00863910

[46] A. Sarkany, Z. Zsoldos, G. Stefler, J. W. Hightower, L. Guczi, J. Catal. 1995, 157, 179. https://doi.org/10.1006/jcat.1995.1278 
[47] M. Meng, P.-Y. Lin, Y.-L. Fu, Catal. Lett. 1997, 48, 213222. https://doi.org/10.1023/A:1019099625781

[48] N. M. Popova, G. A. Savel'eva, Theor. Eksp. Khim. 1991, 27(6), 907-916.

[49] P. Arnoldy, J. A. Moulijn, J. Catal. 1985, 93, 38. https://doi.org/10.1016/0021-9517(85)90149-6

[50] P. J. van Berge, J. van de Loosdrecht, S. Barradas, A. M. van der Kraan, Catal. Today 2000, 58, 321. https://doi.org/10.1016/S0920-5861(00)00265-0

[51] R. Riva, H. Miessner, G. Del Piero, D. Rebours, M. Roy, Stud. Surf. Sci. Catal. (Natural gas conversion V) 1998, 119, 203. https://doi.org/10.1016/S0167-2991(98)80432-1

[52] M.Voß, D. Borgmann, G. Wedler, J. Catal. 2002, 212, 10. https://doi.org/10.1006/jcat.2002.3739

[53] C. H. Bartholomew, M. Rahmati, M. A. Reynolds, Appl. Catal. A: Gen. 2020, 602, 117609. https://doi.org/10.1016/j.apcata.2020.117609

[54] M. Sadeqzadeh, H. Karaca, O. V. Safonova, P. Fongarland, S. Chambrey, P. Roussel, A. GribovalConstant, M. Lacroix, D. Curulla-Ferre, F. Luck, A. Y. Khodakov, Catal. Today 2011, 164, 62-67. https://doi.org/10.1016/j.cattod.2010.12.035

[55] X. Sun, S. Sartipi, F. Kapteijn, J. Gascon, New J. Chem. 2016, 40, 4167. https://doi.org/10.1039/C5NJ02462E

[56] J. Zhang, J. Chen, J. Ren, Y. Sun, Appl. Catal. A 2003, 243, 121. https://doi.org/10.1016/S0926-860X(02)00541-0

[57] A. F. Carlsson, M. Naschitzki, M. Bäumer, H.-J. Freund, J. Phys. Chem. B. 2003, 107, 778-785. https://doi.org/10.1021/jp021966v

[58] M. Heemeier, A. F. Carlsson, M. Naschitzki, M. Schmal, M. Baeumer, H.-J. Freund, Angew. Chem. Int. Ed. 2002, 41, 4073.

https://doi.org/10.1002/1521-3773(20021104)41:21\%3C4073::AIDANIE4073\%3E3.0.CO;2-M

[59] N. M. Popova, L. V. Babenkova, G. A. Savel'eva, Adsorption and interaction of simple gases with VIII group metals, Nauka, Kaz. SSR, Alma-Ata, 1979 (in Russian).

[60] D. Potoczna-Petru, J. M. Jablonski, J. Okal, L. Krajczyk, Appl. Catal. A: Gen. 1998, 175, 113-120. https://doi.org/10.1016/S0926-860X(98)00214-2

[61] K. I. Hadjiivanov, D. G. Klissurski, Chem. Soc. Rev. 1996, 25, 61-69. https://doi.org/10.1039/cs9962500061

[62] D. Lin-Vien, N. B. Colthup, W. G. Fateley and J. G. Grasselli, The Handbook of Infrared and Raman Characteristic Frequencies of Organic Molecules, Academic Press, San Diego, London, 1991, p. 503.

[63] G. Kadinov, S. Todorova, A. Palazov, New Frontiers in Catalysis, Proc. $10^{\text {th }}$ Int. Congr. Catal., Budapest 1924 July, 1992 (Stud. Surf. Sci. Catal., vol. 75), L. Guczi,
F. Solymosi and P. Tetenyi (Ed.), Akademiai Kiado, Budapest, 1993, Part C, p. 2817-2820.

https://doi.org/10.1016/S0167-2991(08)64413-4

[64] L. H. Little, Infrared Spectra of Adsorbed Species, Academic Press Inc., London, New York, 1966.

[65] J. Scalbert, I. Clémençon, P. Lecour, L. Braconnier, F. Diehl, C. Legens, Catal. Sci. Technol. 2015, 5, 4193. https://doi.org/10.1039/C5CY00556F

[66] G. Kadinov, Ch. Bonev, S. Todorova, A. Palazov, J. Chem. Soc. Faraday Trans. 1998, 94, 3027-3031. https://doi.org/10.1039/a804315i

[67] K. Hadjiivanov, G. Vaisilov, Adv. Catal. 2002, 47, 307-511. https://doi.org/10.1016/S0360-0564(02)47008-3

[68] J. A. Singh, N. Yang, X. Liu, C. Tsai, K. H. Stone, B. Johnson, A. L. Koh, S. F. Bent, J. Phys. Chem. C 2018, 122, 2184-2194. https://doi.org/10.1021/acs.jpcc.7b10541

[69] T.-Y. Chen, J. Su, Z. Zhang, C. Cao, X. Wang, R. Si, X. Liu, B. Shi, J. Xu,Y.-F. Han, ACS Catal. 2018, 8, 86068617. https://doi.org/10.1021/acscatal.8b00453

[70] L. Lemaitre, A. Berliet, S. Maury, M. Rivallan, Catal. Today, 2017, 283, 172-175.

https://doi.org/10.1016/j.cattod.2016.02.033

[71] G. Prieto, A. Martinez, P. Concepcion, R. MorenoTost, J. Catal. 2009, 266, 129-144.

https://doi.org/10.1016/j.jcat.2009.06.001

[72] U. Cornaro, S. Rossini, T. Montanari, E. Finocchio, G. Busca, Catal. Today 2012, 197, 101-108. https://doi.org/10.1016/j.cattod.2012.07.005

[73] N. Kumar, K. Jothimurugesan, G. Stanley, V. Schwartz, J. Spivey, J. Phys. Chem.C 2011, 115, 990-998. https://doi.org/10.1021/jp104878e

[74] J. Couble, D. Bianchi, Appl. Catal. A: Gen. 2012, 445446, 1-13.

https://doi.org/10.1016/j.apcata.2012.07.017

[75] V. Sanchez-Escribano, M. A. Larrubio-Vargas, E. Finocchio, G. Busca, Appl. Catal. A: Gen. 2007, 316, 68-74. https://doi.org/10.1016/j.apcata.2006.09.020

[76] Z. Yan, Z. Wang, D. B. Bukur, D. W. Goodman, J. Catal. 2009, 268, 196-200.

https://doi.org/10.1016/j.jcat.2009.09.015

[77] C. E. Cliewer, S. L. Soled, G. Kiss, Catal. Today 2019, 323, 233.

https://doi.org/10.1016/j.cattod.2018.05.021

[78] G. Blyholder, J. Phys. Chem. 1964, 68, 2772-2777. https://doi.org/10.1021/j100792a006

[79] A. Rabo, A. Risch, M. Poutsma, J. Catal. 1978, 53, 295311. https://doi.org/10.1016/0021-9517(78)90102-1

[80] D. C. Grenoble, M. M. Estadt, D. F. Ollis, J. Catal. 1981, 67, 90.

[81] L. Fan, L. Zhang, Y. Shen, D. Liu, N. Wahab, M. M. Hasan, Bull. Chem. Reac. Eng. Catal. 2016, 11, 354. https://doi.org/10.9767/bcrec.11.3.575.354-362 